\title{
Criminal Law Exceptionalism as an Affirmative Ideology, and its Expansionist Discontents
}

\section{Christoph Burchard ${ }^{1,2}$}

Accepted: 15 September 2021 / Published online: 31 October 2021

(C) The Author(s) 2021

\begin{abstract}
Criminal law exceptionalism, or so I suggest, has turned into an ideology in German and Continental criminal law theory. It rests on interrelated claims about the (ideal or real) extraordinary qualities and properties of the criminal law and has led to exceptional doctrines in constitutional criminal law and criminal law theory. It prima facie paradoxically perpetuates and conserves the criminal law, and all too often leads to ideological thoughtlessness, which may blind us to the dark sides of criminal laws in action.
\end{abstract}

Keywords Criminal law exceptionalism · Ideology · Ideological thoughtlessness · Dark sides of criminal laws

\section{Introduction}

The supposed exceptionalities of the criminal law still ${ }^{1}$ serve as the rallying point for conventional German and Continental (European) criminal law theory, ${ }^{2}$ which seeks "a defensible account of criminal law and punishment as distinctively valuable" (as Matravers in this symposium expounds so exceptionally well). As I will argue in this essay, many claims about the exceptionalities of the criminal law have turned into

\footnotetext{
1 Yet see Francesco Viganò, this issue, who moves to lay this to rest, especially from the perspective of what I call constitutional criminal law and doctrine.

${ }^{2}$ I focus on Germany and, to a lesser degree, Continental Europe here. Ristroph in this issue identifies parallel developments in the USA. On exceptionalism in Continental criminal law theory, also see Viganò in this issue as well as, pars pro toto, Wolfgang Naucke, Negatives Strafrecht (Münster: LIT Verlag, 2015), p. 60.

Christoph Burchard

burchard@jur.uni-frankfurt.de

1 Chair for German, European and International Criminal Law and Procedure, Comparative Law and Legal Theory, Goethe-University Frankfurt, Frankfurt, Germany

2 Principal Investigator at the Research Initiative "ConTrust: Trust in Conflict. Political Coexistence under Conditions of Uncertainty", Frankfurt, Germany
} 
an affirmative ideology. ${ }^{3}$ It ultimately perpetuates and conserves the criminal law, and links how it is theorized with how it is practised. ${ }^{4}$ Criminal law exceptionalism as an affirmative ideology tells a grand narrative about the superior otherness of "the modern liberal criminal law" from ordinary bodies of law and other means of ordering human sociality. Indeed, the supposed exceptionality of the modern liberal criminal law serves as a foundational idea and ideal, which then fuels distinct normative principles that (are to) shape how the criminal law is theorized, legislated, administrated, and adjudicated (Sect. 2). However, criminal law exceptionalism all too often leads to ideological thoughtlessness (Sect. 3), and is thus liable to blind us to the dark sides of criminal law in action. It thereby generates the apparent paradox that criminal law exceptionalism does not necessarily (as many theorists would have it) restrict and minimalize the criminal law as a means of social governance, but rather perpetuates and even expands and intensifies the penal state and the sufferings it causes. Criminal law exceptionalism, therefore, is an affirmative ideology which may have a critical agenda that favors criminal law minimalism, ${ }^{6}$ but which de facto allows for the perpetuation of the status quo. This paper, then, bridges the ideal and the critical approach to the question "Is criminal law exceptional?" by being mindful of the practical effects of ideal(ized) theory.

\section{Affirmative Claims of Exceptionality}

Criminal law exceptionalism is an amalgam of several claims about (ideal or real) exceptionalities (as in exceptional qualities and properties) of the criminal law: it is important to note that these claims are (as I will elaborate in my discussion of the other essays in this symposium) ultimately normative ${ }^{7}$ as well as affirmative.

On a foundational level, punishment and stigmatization are considered extraordinarily harsh means of addressing deviance in a liberal society (burden

\footnotetext{
3 Which already follows from the suffix "-ism". Ristroph in this issue considers exceptionalism a "mode of thought". The suffix "-ty" or "-ness" denotes specific qualities, conditions and properties, as in the "exceptionality", "distinctiveness" (see Antony Duff and Sandra Marshall, this issue) or "specialness" (see Matt Matravers, this issue) of the criminal law.

${ }^{4}$ For my prior reflections on this issue, albeit in German, see Christoph Burchard, "Strafrechtslimitation als Motor der Strafrechtsexpansion", in Milan Kuhli and Martin Asholt (eds.), Strafbegründung und Strafeinschränkung als Argumentationsmuster (Baden-Baden: Nomos, 2017), 21.

5 I will return to the "the" later. It implies the all-encompassing aspirations of criminal law exceptionalism. I will refer to "criminal law" or even "criminal laws" to break with these aspirations. "Liberal" I use in the sense of distributing freedoms and liberties between equal citizens who enjoy human dignity.

${ }^{6}$ Which includes favoring criminal law minimalism over abolitionism, as discernable in Máximo Langer, "Penal Abolitionism and Criminal Law Minimalism", Harvard Law Review Forum 134 (2000): 42.

7 Javier Wilenmann in this issue subscribes to "descriptive (i.e.: non-normative) goals connected to the distinctiveness question." The distinction between the descriptive and the normative (or the real and the ideal, or the is and the ought) is difficult to uphold, however, as description can rarely be truly neutral. It comes as no surprise, then, that affirmative claims of criminal law exceptionality usually feature historical, descriptive and normative elements. Likewise, non-affirmative claims about criminal law exceptionality are rarely solely descriptive, but have a critical dimension to them.
} 
exceptionality $^{8}$ ). Although there is a quasi-unanimous agreement in Continental discourse that criminal law is part of public law, the (real or imaginary) harshness of its residual ${ }^{9}$ sanctions (and the corresponding sanctioning apparatus) sets it apart from administrative, let alone civil law. ${ }^{10}$ This often goes hand-in-hand with a claim of efficacy exceptionality, ${ }^{11}$ according to which the criminal law is especially capable both of influencing ${ }^{12}$ humans as rational actors (after all, the commands of the criminal law are backed up, or so the story goes, by extraordinary burdens ${ }^{13}$ ) and of thereby guaranteeing the "uncertain certainty" of its normatively promised future. ${ }^{14}$ Finally, the assertion of subject-matter exceptionality is intrinsically intertwined ("chicken-or-egg" like) with burden and efficacy exceptionality; it "claims that criminal law addresses $[\ldots]$ a discrete set of particularly harmful or wrongful behaviors, ${ }^{15}$ which the criminal law can (and even: has to ${ }^{16}$ ) address.

Derivative from this are special doctrines in German and Continental criminal law theory. They stand for the doctrinal exceptionality of the criminal law: Burden, efficacy and subject-matter exceptionality are turned into a discrete and unique set of doctrines and principles (some of which have achieved constitutional status ${ }^{17}$ ). For example, (1) the so-called Rechtsgut doctrine-which still dominates criminal law scholarship in Germany and in many jurisdictions that lean on German Dogmatikasserts that "one" 18 must only resort to criminal law to protect a Rechtsgut (a highly amorphous and likely also circular concept that is hardly translatable into English; a literal translation is "legal value" or "legal good"). The Rechtsgut doctrine represents the normative extension and validation of subject-matter exceptionality. For

\footnotetext{
8 Alice Ristroph, "An Intellectual History of Mass Incarceration", Boston College Law Review 60(7) (2019): 1949, p. 1953 ff., refers to "burden exceptionalism".

${ }^{9}$ I am not arguing that criminal law and punishment are (seen as) the same. The commands of criminal laws ("Thou shall not kill!" etc.) do not necessarily work with overt coercion, but rather because of noumenal power (Rainer Forst, "Noumenal Power", The Journal of Political Philosophy 23 (2) (2015): 111). But according to (the claim of) burden exceptionality, the possibility of resorting to exceptionally harsh burdens (punishment) renders the criminal law exceptional. Therefore, the existence of extraordinary burdens in other areas of law (think of child custody being transferred to one parent; or of sex offender registrations that are openly available to the general public) puts the exceptionality of criminal law in doubt, and ultimately leads to the question whether punishment is indeed distinctive, e.g. because of the expressive role of censure that goes along with it.

${ }^{10}$ Viganò and Matravers in this issue rightly question whether this is correct as a matter of practice.

${ }^{11}$ It is noteworthy that efficiency (achieving maximum results with minimum expense) is not really a matter of concern in German and Continental criminal law theory.

12 Or, to succumb to the functional logic of social governance, "regulating".

13 Viganò in this issue argues that many scholars assume that criminal sanctions are unique because of their expressive character. It stands to reason that expressive exceptionality is derivative from burden and efficacy exceptionality. On the one hand, being censured (by being punished) is considered the exceptional burden that sets the criminal law apart (even when sanctions are substantively converging across legal realms, as in criminal fines vis-á-vis tort damages). On the other hand, censure builds on a presumption of "normative responsiveness" (of the offender, the victim, the public).

14 "Thou shall not kill!" implies the promise of "Thou will not be killed!".

${ }^{15}$ Ristroph, n. 8 above, p. 1954.

${ }^{16}$ As in "duties to criminalize and prosecute".

${ }^{17}$ See Viganò, this issue.

${ }^{18}$ This "one" encompasses democratic legislators!.
} 
example, it seeks to prohibit the criminalization of mere social taboos, since taboos do not represent protected legal values. (2) Under the ultima ratio test, which draws on and normatively confirms burden, efficacy and subject-matter exceptionality, "one" must only resort to criminalization as a last resort, i.e. if there is no other, less intrusive means that is equally suited to accomplish the intended objective (the protection of a Rechtsgut). (3) The nullum crimen sine lege principle demands that criminal statutes be sufficiently determined by parliament before the criminal act so that, inter alia, an individual can reasonably foresee her risk of punishment. This inter alia takes up efficacy exceptionality, since it presupposes and reinforces the capability of the criminal law to influence human behavior. (4) The Schuldprinzip (the culpability or guilt principle) takes up and entrenches burden, subject-matter and efficacy exceptionality: the exceptional burden of punishment for extraordinary wrongs is only justified, but can indeed be justified, because of individual culpability for the criminal act (which German doctrine summarizes as "the possibility to have acted otherwise"). (5) Finally, these allegedly restrictive doctrines are now complemented by constitutional duties to criminalize and effectively prosecute.

\section{Affirmative Ideology and Ideological Thoughtlessness}

All of these exceptionalities (burden, efficacy and subject-matter as well as doctrinal exceptionality) have turned into an overarching ideology in German and Continental criminal law theory: Criminal law exceptionalism claims the exceptionality of the liberal criminal law per se.

Exceptionalism as ideology purports (often by ahistorically claiming historical continuities) to identify common maxims, ideas and ideals that characterize an (alleged) essence (or core or nucleus) of the liberal criminal law as something inherently different, unique and superior: The criminal law is and ought to be superiorly terrible (because of burden exceptionality ${ }^{19}$ ), superiorly regulative (because of efficacy exceptionality) and superiorly expressive (because of subject-matter exceptionality). That is why the (legislation and administration of the) criminal law requires superior restrictions, checks and balances (as guaranteed by doctrinal exceptionality, e.g. by the ultima ratio test or the Schuldprinzip). What is more, the very notion that there exists "the criminal law"-a definitive article that spans borders, ages, and regime rationalities (in e.g. treating ordinary traffic, sex, as well as white-collar offenses alike)_illustrates the all-encompassing aspirations of criminal law exceptionalism.

Criminal law exceptionalism is an artefact; one that is created, cultivated and maintained by human thinking and practice. This tells us much about how we (as academics, policy entrepreneurs, citizens) strive for a "the": a nature, concept, nucleus or essence of "the" criminal law as such. This essentialism is a driving force behind criminal law exceptionalism, and it seeks to rationally reconstruct some

\footnotetext{
19 Viganò in this issue notes that "[t]he ius puniendi continues to work as a ius terribile, albeit not in the extreme form that it used to do in the past."
} 
distinct sense, idea and ideal in the complexities ("the messy world" ${ }^{20}$ ) of criminal laws in actions. ${ }^{21}$ What is more, criminal law exceptionalism is connected to power, especially to "penal aristocracy" 22 in Continental Europe: the (real or imaginary) sway that doctrines (and ergo academics) hold over the legislation, administration and adjudication of criminal justice. Or to put it more generally, criminal law exceptionalism in criminal law theorizing should not-as a matter of one's ethics of responsibility ${ }^{23}$ - be detached from its real-life effects. After all, "[c]riminal law is a human practice, and theorizing criminal law is itself part of the practice." 24

Criminal law exceptionalism all too often leads to ideological thoughtlessness, and criminal law (and punishment) therefore all too often appears to be more a matter of necessity than of choice. ${ }^{25}$ For because of ideological thoughtlessness "we fail to appreciate that there is anything to which we ought to respond at all. [Ideological thoughtlessness leads] to the naturalization of a contingent world; and, with it, the disappearance of suffering as a problem to confront. ${ }^{\circ 26}$ In the case at hand, ideological thoughtlessness allows for the perpetuation and expansion of criminal law under the pretense of principles that many would argue (most of them seriously!) serve restrictive purposes. Somewhat paradoxically, then, criminal law exceptionalism prepares fruitful soil for the current affirmations of punitiveness in Germany and Europe. Suffice it to lay out three grounds for this diagnosis:

First, what is conspicuously missing in criminal law exceptionalism are (acknowledgments of) the "dark sides" of criminal laws in action. ${ }^{27}$ On a foundational level, criminal law exceptionalism misses the criminal law's intimate connections to power, to (the possibility of) discrimination, and to the conservation of the status quo. And on the level of doctrine and principles, it rarely accounts for insights which other disciplines, including criminology, have long since put on the table. For instance (1) that the administration of criminal justice is usually selective and dysfunctional (this, for example, is conspicuously missing in the doctrinalization of the ultima ratio test). (2) That criminal law cannot in fact guide human decision-making

\footnotetext{
20 See Javier Wilenmann in this issue.

21 Which is crucial for a normative "science of criminal law" (Strafrechtswissenschaft in German).

22 Massimo Donini, "Metodo democratico e metodo scientifico nel rapporto fra diritto penale e politica", Rivista italiana di diritto e procedura penale 44(1) (2001): 27. Bernd Schünemann, for example, has famously and in all seriousness described German Dogmatik as a fourth power, one that does not govern, but only restricts the traditional three branches of government, see e.g. Bernd Schünemann, "Über Strafrecht im demokratischen Rechtsstaat, das unverzichtbare Rationalitätsniveau seiner Dogmatik und die vorgeblich progressive Rückschrittspropaganda”, Zeitschrift für die Internationale Strafrechtsdogmatik 11(10) (2016): 654, p. 664.

23 As I have argued in Burchard, n. 1 above.

24 Ristroph, this issue. Much can and should be said about whether this also holds true for those who favor truly ideal criminal law theorizing over its non-ideal (to put it mildly) practice. On this, also see Matravers in this issue.

25 Lorca in this issue rightly questions this and turns it around.

26 Such is Jacob Schiff's ("The varieties of thoughtlessness and the limits of thinking", European Journal of Political Theory 12(2) (2013): 99, p. 106) interpretation of Hannah Arendt, The Human Condition (Chicago: University of Chicago Press, 1998).

27 See Ralf Kölbel, "Die dunkle Seite des Strafrechts”, Neue Kriminalpolitik 31(3) (2019): 249, also for the upcoming diagnosis.
} 
to the extent that we theoretically presuppose (for instance in theoretically treating white-collar criminals and sex offenders alike). (3) And that the criminal law runs on a negation of social complexity, as the aspiration to ascribe individual responsibility/culpability necessarily both de-contextualizes the criminal act and socially isolates the offender.

While this third point is oftentimes easily forgotten, there are those who are well aware of it, but who make a virtue out of necessity by turning the (pejoratively connotated) negation of social complexity into a (positively connotated) realization of human agency: They assert that the ascription(or supposed finding) of criminal responsibility is supreme ${ }^{28}$ in realizing human agency as the bedrock of a liberal society. For only punishment (which is commonly considered the natural counterpart of criminal responsibility) truly honors the citizen who commits a grave wrong against her co-citizens as an equal in a society composed of equals-or so it is argued in Hegelian terms. ${ }^{29}$ This claim of agency exceptionality bolsters criminal law exceptionalism as a prima facie liberal ideology. But it again fails to acknowledge the "dark sides" of criminal law. And in taking advantage of the other (claimed or mythical) exceptionalities identified above, it does not explicate just why criminal punishment and responsibility are really necessary to realize (and indeed capable of realizing) human agency in complex social settings, and why there are no other ways to do so.

This is where criminal law exceptionalism, due to its essentialism, becomes highly conservative, a force that does not (aspire to) critically reflect on the existing realities of criminal laws in action.

Second, the foundational exceptionalities that underpin criminal law exceptionalism have an inherent expansionist drift. And their underlying essentialism assists the formation of surprising coalitions of the willing (of those who wish to expand the criminal law, and those who are at heart complacent about it).

Burden exceptionalism speaks to those who seek to be (seen as) tough on crime. But curiously enough, it also relaxes those who wish to be more penally lenient, because the (supposed) humanization of punishment ${ }^{30}$ leads to diminished concerns about how much punishment does (not) encroach upon fundamental values like freedom or dignity. Therefore, with punishment becoming increasingly expressively overdetermined, ${ }^{31}$ its burdens no longer serve as an unequivocal reason to restrict criminal law.

Efficacy exceptionalism casts the criminal law as the most effective resolution of social deviance or social conflict. This becomes particularly apparent in its doctrinal mirror, the ultima ratio test. By definition, criminal laws are the sharpest sword

\footnotetext{
${ }^{28}$ In contrast to non-legal, e.g. moral responsibility or mere administrative or civil liability.

29 For an overview cf. Klaus Roxin and Luís Greco, Strafrecht Allgemeiner Teil (München: C.H. Beck, 2020, 5th edn.), p. 131.

30 See Viganò, this issue.

31 This holds especially true for imprisonment, which "is endowed with a sufficiently rich and diverse array of meanings that persons of diverse worldviews - solidaristic and individualistic, hierarchic and egalitarian - can all find affirmation of their values in it simultaneously." Dan M. Kahan, "What's Really Wrong with Shaming Sanctions”, Texas Law Review 84(7) (2006): 2075, p. 2076.
} 
available to a legislature; and it is well within its ius puniendi to exceptionally resort to criminal law if supposedly ordinary (e.g. administrative or civil) means prove ${ }^{32}$ to be duller weapons with which to achieve the relevant goal. Yet these other means, again by definition, are duller, inter alia because by definition they do not carry the same regulative or expressive sway over the individual. This shifts the burden of argumentation onto the critic. Someone who wishes to abolish or curtail criminal laws must demonstrate (with respect to criminal legislation that is already in place: counterfactually so!) that other means are at least as capable of achieving the goals of these criminal laws. That is why (full as well as partial) abolitionists face an uphill battle: How would a state be able to uphold social peace, to inhibit personal vendettas, to solidify its authority, or to seriously protect Rechtsgüter without the criminal law as it is $?^{33}$ That is the conservative question of criminal law exceptionalism, and this is why affirmative claims about the exceptional status of the criminal law perpetuate and consolidate the penal state in practice.

Subject-matter exceptionalism, finally, offers a standing invitation to those who wish to draw on the symbolic capital of the criminal law for their political ends. ${ }^{34}$ In today's pluralistic societies, especially in liberal democracies, ${ }^{35}$ criminal law seems among the remaining few means of hypostatizing shared beliefs, e.g. about what constitutes particularly harmful or wrongful behavior. ${ }^{36}$ Others are invited to draw on the criminal law to denominate what should be flagged as an exceptional harm or wrong (think about the introduction of environmental crimes from the 1970s onward; or about the role that criminal law plays in today's identity politics ${ }^{37}$ ). This, then, is where criminal law exceptionalism fosters a curious alliance between conservative-reductionists and progressive-expansionists. And where normative and descriptive accounts of criminal law's exceptionality coalesce. ${ }^{38}$

Third, as already noted, under conventional German and Continental criminal law theory, normative exceptionalism aims solely to set limits to criminal law (because it is so harsh, and only addresses exceptional wrongs and harms etc.). This is why criminal law exceptionalism is conventionally cast as a restrictive and critical

\footnotetext{
32 Constitutionally speaking, no empirical proof is required. A (non-arbitrary) assumption by parliament is sufficient under German constitutional criminal law.

33 To escape this question, Rocío Lorca in this issue hence argues that "criminal law is not exceptional" and that we "we can still make sense of the idea of a modern state and individual rights" without criminal law.

34 Note that I am not criticizing this political approach to criminal law per se. I am merely suggesting that criminal law exceptionalism invites an overuse of the criminal law for political purposes.

${ }^{35}$ In this issue, Matravers argues to that end. "Liberal democracy is a fragile achievement without foundations beyond the wills of the persons involved. In sustaining this, criminal law can play a distinct constitutive role in affirming the common good of the parties."

36 This is likely why even critical minds draw on violent crime to reject abolitionist demands: "We at least need the criminal law to protect against attacks on highly personal Rechtsgüter! —or so they would argue.

37 See Aya Gruber, The Feminist War on Crime (Berkeley: University of California Press, 2020).

38 See Wilenmann, this issue: "[C]riminal law directly expresses wrongfulness and blame. When the politics of signification reach symbolic objects and issues, criminalization becomes an almost irresistible political tool.".
} 
mindset. Yet limitations not only disqualify that which is excluded-for example because it is too terrible (a criminal punishment is too harsh), or needless (a criminal statute does not meet the ultima ratio test), or contrary to human dignity (strict liability offenses violate the Schuldprinzip). Limitations mutatis mutandis also justify that which is included-e.g. because it is appropriate (a criminal statute provides just punishment for a grave wrong), necessary (for the serious protection of a Rechtsgut etc.), or a supreme recognition of human agency.

This has a potential expansionist drift in the constitutional state. On the one hand, because this justificatory dimension is easily overlooked, and hence leads to complacency among those who should be critical about criminal laws in action. On the other hand, because in Germany and many European jurisdictions it ultimately falls to political actors to make the pivotal determinations. For example, it is well established that new Rechtsgüter are easy to come up with (as when leading voices in the German Bundestag invented the "integrity of sporting competition" to justify its 2014 anti-doping legislation). What is more, under German constitutional law, parliament enjoys a considerable margin of appreciation to determine whether criminal legislation is required, necessary and appropriate, i.e. whether it factually meets the proportionality and the ultima ratio test. This is where the failure of criminal law exceptionalism to account for power ("Quis iudicabit" whether a resort to criminal law is warranted?) becomes most evident. But this is also where the "constitutional normalization" of criminal legislation ${ }^{39}$ offers new chances. Namely (if and) because constitutional theory and practice are well-versed in dealing-as Viganò makes so abundantly clear in his discussion - with questions of political power and its separation between political actors in constitutional democracies (e.g. between legislators and courts, which may enjoy the power to judicially review, to uphold or to strike down criminal laws). A "constitutional normalization" should therefore pave the way for a criminal law theory that foundationally accounts for the polity that constitutes (or in more ideal terms: ought to constitute) criminal law(s) — an issue already raised by Duff and Marshall in this symposium.

\section{De-exceptionalization as a Means to Deescalate Criminal Law?}

As I have argued in this short essay, criminal law exceptionalism in Germany and Continental Europe traditionally aspires to restrict or minimize the liberal criminal law. Yet in so doing, it does not challenge the criminal law per se, but affirms it (at least some ideal of it). Because it has turned into an all-encompassing ideology, it is prone to ideological thoughtlessness. It fails to realize that it builds on descriptive and normative premises which in light of today's broader societal and political contexts (the constitutional state, the pluralization of society, identity politics etc.) cater to the expansion and intensification of criminal laws.

Exceptionalism fails as an ideology to restrict and critically reflect upon criminal laws; it rather turns into an ideology that realistically speaking fosters the

\footnotetext{
${ }^{39}$ See again Viganò, this issue.
} 
conservation of the status quo and even the expansion of the penal state. Where then should we turn in order to deescalate and critically question the ius puniendi of the state? In this respect, the de-exceptionalization of a non-ideal criminal law seems a promising path forward. ${ }^{40} \mathrm{~A}$ de-exceptionalizing approach would follow the political turn in criminal law theory by breaking with the essentialism of conventional criminal law theory. It would need to account for the shortcomings of criminal law in general (e.g. in regulating human behavior) and the "dark sides" of the administration of criminal justice. And it would need to accommodate the political dimensions of and in criminal laws. ${ }^{41}$ But all this is another story.

\section{Discussion}

There are three points that I would like to clarify in light of the other essays in this special issue.

First, Matravers is right that criminal law exceptionalism as an affirmative ideology is a "community stew" of ideas. But then, in most ideologies as all-encompassing narratives proponents are free to weigh individual "ingredients" (burden, efficacy, subject-matter, normative exceptionality) differently, and to add other components (such as agency exceptionality) as long as the exceptionality of the criminal law is not genuinely doubted. This narrative, I would like to highlight, is not based on the criminal law as an apolitical institution that merely vindicates private right, ${ }^{42}$ and my critical analysis of criminal law exceptionalism is hence not directed against this school of thought (which is far less influential in German and Continental criminal law theory). Rather, I posit that criminal law exceptionalism fosters curious alliances. It aligns moral philosophical (pre-state, individualistic, and/or backwardlooking) with overt political (statist, collective, and/or forward-looking) affirmations of the criminal law. For all camps can and do draw on certain supposed exceptionalities of the criminal law to further their respective agendas (e.g. that the criminal law is particularly suited to hold offenders to account, be it for retributive or for therapeutic reasons). Put differently, there is more to exceptionalism than criticizing (or justifying) the remnants of moralism in criminal law.

Second, other contributions to this special issue-especially those by Lorca and Wilenmann-have already led me to clarify my main text as follows: The criminal law exceptionalism that concerns me is not "only" an ideology, but an affirmative and essentialist one. It neither fundamentally challenges the "the" in the criminal law; nor is it radically critical of the criminal law as an institution in our modern

\footnotetext{
$\overline{40}$ Which is less radical than the resurgence of abolitionism in many jurisdictions outside of Europe.

41 By "the political" I refer to the ordinary fact of justificatory pluralism in a non-ideal world where normative choices are unavoidable, so that the objectively undecidable is to be authoritatively decided within and without the criminal law. Compromise, then, needs to become more important in criminal law theory (see Stephanie Classmann, Criminal Law as Modus Vivendi, dissertation draft on file with the author). The same holds true for contestation and change.

42 The protection of collective Rechtsgüter is well-accepted in German and Continental doctrine, although it often invites criticism from certain liberal schools of thought.
} 
states (be it the administrative or the welfare state, or the minimal state: both prototypical setups rely on the criminal law to further the internalization and habitualization of their respective objectives on the part of their respective citizens or subjects). Many proponents of criminal law exceptionalism aspire to reform and minimize the criminal law. But by doing so, they can no longer seriously and fundamentally contest the penal state. By way of example, consider the claim of burden exceptionality. This, too, eventually caters to affirmation and perpetuation. After all, the evil (Bentham) that the criminal law entails is not something that eo ipso speaks against it, for this evil can be outweighed by the value and/or utility of the criminal law, if only in extraordinary circumstances (subject-matter exceptionality) and with extraordinary protections (doctrinal exceptionality).

Third, there are critical appraisals of certain exceptional features of the criminal law (its idealization) or of criminal laws in actions (their real practice). And I understand Wilenmann's contribution not so much as a merely descriptive account of the exceptionality of the criminal law, but as one that prepares for a critique of the practices of criminal law in action. Very summarily speaking, one could argue from a critical stance (1) that the moral rhetoric of criminal law theory and practice very effectively (ergo exceptionally) obfuscates the underlying social conflicts; (2) that criminal responses promise easy political (again: ergo politically exceptional) solutions to address social conflicts (the criminal law turns into a political prima ratio, and indeed often a sole response, because it is a doctrinal ultima ratio); (3) that the focus on individual responsibility very successfully blinds us to possible collective responsibilities; and (4) that the actual administration of criminal laws can be grossly discriminatory and racist. ${ }^{43}$

But these critical diagnoses (about exceptionally "dangerous" features of criminal law - to again reference Matravers in this symposium) have not, curiously enough, generated any tangible abolitionist or at least disaffirmative momentum in Germany and Continental Europe, or grosso modo in criminal law theory per se. After all, the criminal law seems like something that we (especially we as criminal law theorists) cannot not want, inter alia because - as is rightly challenged by Lorca in this issue - the criminal law seems key to upholding social peace, to inhibiting personal vendettas, and to protecting individual rights and liberties (again something that we seemingly cannot not want). Put differently, then, my analysis ultimately seeks to put the following question on the table (which is not a rhetorical one, but one that I do not know the answer to): To what extent is-even when it advances critical agendas of reform and criminal law minimalism - a criminal law theory that is driven by criminal law exceptionalism as an affirmative ideology responsible for the (stabilization and expansion of as well as the suffering in the) penal state?

Funding Open Access funding enabled and organized by Projekt DEAL.

\footnotetext{
43 As can be seen in the intense discussions about mass incarceration in the USA, which at times glance over other socially important areas of discrimination and racism, such as health-care and education.
} 
Open Access This article is licensed under a Creative Commons Attribution 4.0 International License, which permits use, sharing, adaptation, distribution and reproduction in any medium or format, as long as you give appropriate credit to the original author(s) and the source, provide a link to the Creative Commons licence, and indicate if changes were made. The images or other third party material in this article are included in the article's Creative Commons licence, unless indicated otherwise in a credit line to the material. If material is not included in the article's Creative Commons licence and your intended use is not permitted by statutory regulation or exceeds the permitted use, you will need to obtain permission directly from the copyright holder. To view a copy of this licence, visit http://creativecommons.org/licen ses/by/4.0/.

Publisher's Note Springer Nature remains neutral with regard to jurisdictional claims in published maps and institutional affiliations. 